\title{
Red Meats and Processed Meat as the Carcinogenic Foods and Phytochemical-chemoprevention
}

\author{
Anna Meiliana ${ }^{1,2,}$, Nurrani Mustika Dewi², Andi Wijaya ${ }^{1,2}$ \\ ${ }^{1}$ Postgraduate Program in Clinical Pharmacy, Padjadjaran University, Jl. Eijkman No.38, Bandung, Indonesia \\ ${ }^{2}$ Prodia Clinical Laboratory, Jl. Cisangkuy No.2, Bandung, Indonesia \\ *Corresponding author. E-mail: anna.meiliana@prodia.co.id
}

Received date: Aug 13, 2019; Revised date: Oct 31, 2019; Accepted date: Nov 1, 2019

\section{Abstract}

B ACKGROUND: Along with its increased prevalence, in the past decade, cancer had joined the list of chronic debilitating diseases. Nutrition become substantial aspects, due to its time-dependent effect to modulate inflammation thus trigger carcinogenic effects by altering the immune check point. Thus, nutrition contributes to the progression and therapeutic response of cancer, both in human or animal models.

CONTENT: Meat is well favored food with appreciable appealing. Due to its high nutritional values it plays a central role in human development. Meat or meat derivate are important sources of proteins, minerals and vitamins. Their nutritional importance is worth compare to their economic impact but recent publication of WHO has set the social alarm about the relationship between red and/or processed meat consumption and cancer. On the other side, some natural or biologic agents may inhibit or reverse tumor growth. Some phytochemical agents including curcumin, resveratrol, lycopene, folates and tea polyphenols clinically proved to tune the signaling pathways regulating cell proliferation and apoptosis in transformed cells, enhance the host immune system and sensitize malignant cells to cytotoxic agents.

SUMMARY: Recent studies on chemopreventive agents involves a wide range of molecules, natural (plants, fruits and vegetables) or synthetic will provide better insights for cancer early pathogenesis, important end-point biomarker, and finally potential for reducing the burden of cancer.

KEYWORDS: blocking agents, suppressing agents, red meat, processed meat, chemoprevention, phytochemicals

Indones Biomed J. 2019; 11(3): 225-39

\section{Introduction}

Cancer is a set of diseases in which normal cells undergo neoplastic transformation through a series of incremental steps that occur under selective pressure. Any change can be critical to tipping the scales toward the progression to malignancy. $(1,2)$ Cancer is a complex disease with genetic, environmental, clinical, and lifestyle factors, all of which contribute to tumor initiation until malignant progression.(3) In this review, we highlight that somehow cancer could be termed as an inflammatory disease, and how the nutrition by the time will impact as the pro and contra on carcinogenesis process, especially the red meat and processed meat versus some beneficial phytochemical on the contrary.

Recent data appears to confirm that oxidative stress may have a big role in malignant transformation in primary tumors to augment their metastatic potential. A paper published in 2015 suggested the importance of increased production of reactive oxygen species (ROS) to enable and sustain a highly metastatic phenotype, although many opinions still debate for the controversial role of ROS and antioxidants in cancer.(4,5) Previously, cancer thought to be originated from cell autonomous defects (1), but now it become clear that a complex microenvironment engaged the cancer cell in stimulatory or inhibitory interactions 
with stromal components. Chronic inflammation could consequence in arising cancer, when malignant cells escape from or suppress immunosurveillance mechanisms.(6) In other words, inflammation and immune process can either stimulate or restrain carcinogenesis and tumor progression, respectively.(7-10)

Red meat contains high biological-value proteins and important micronutrients such as omega-3-polyunsaturated fatty acids, B vitamins, iron (both free iron and heme iron), and zinc. The fat content of red meat varies depending on animal species, age, sex, breed, and feed, and the cut of the meat. Meat processing, such as curing and smoking, can result in formation of carcinogenic chemicals, including $\mathrm{N}$-nitroso-compounds (NOC) and polycyclic aromatic hydrocarbons (PAH). Cooking improves the digestibility and palatability of meat, but can also produce known or suspected carcinogens, including heterocyclic aromatic amines (HAA) and PAH. High-temperature cooking by panfrying, grilling, or barbecuing generally produces the highest amounts of these chemicals.(11,12) The International Agency for Research on Cancer (IARC) assessed more than 800 epidemiological studies that found the association of cancer with consumption of red meat or processed meat in many countries, from several continents, with diverse ethnicities and diets.(13)

Chemoprevention can be simply defined as using agents or compounds either natural or synthetic to inhibit tumorigenesis or tumor progression. The agents included here might perform their roles either by blocking cancer causing agents so that the DNA mutation will not be allowed, increasing the DNA repairing system or acting on cells with modified DNA, decreasing the cell cycle speed or interfere with events necessary for tumor spreading through metastasis. The classic mechanisms may involve free radical scavenging enzymes activation, chronic inflammation control, and specific signaling pathways downregulation. More recent understanding involving epigenetic aspects suggested several chemo preventive agents such as sulforaphane, green tea derived compounds, resveratrol, isoflavones, etc. Chemoprevention can give benefits on people with cancer or those without cancer but have a higher risk of developing it.(14-18)

\section{Oxidative Stress, Inflammation and Cancer}

Almost every mechanism in carcinogenesis involving chronic inflammation, from cellular transformation, promotion, survival, proliferation, invasion, angiogenesis, and metastasis $(19,20)$, exemplified by many cases such as reflux esophagitis, gastritis, inflammatory bowel disease, silicosis-associated lung cancer, asbestosis-induced mesothelioma and various types of hepatitis induced by viruses, alcohol consumption or a Western-style diet (21). The carcinogenic effects of inflammation may be dependent on chronic stimulation of cellular turnover, which affect in increased stem-cell divisions, thus local mutagenic effects. The agent that cause inflammation itself can promote mutagenesis, enhanced by ROS production either as a side product of locally enhanced metabolism or are generated specifically by macrophages.(22) Nutrition now known to influence inflammation and immune response, promote the development of the dietary inflammatory index and immunonutrition as the term in epidemiological and clinical studies.(23-25) Figure 1 showed how qualitative and quantitative imbalances in food intake chronically predispose organisms, modulating a state of chronic inflammation in a manner dependent on or independent of the immune system, thus affecting to a time-dependent deterioration in function that culminates in the development and progression of cancer.

Caspase-1 activation complexes (inflammasomes), as their name imply, play a critical role in autoinflammatory syndromes, refer to conditions featuring recurrent episodes of systemic inflammation without (known) pathogens, autoantibodies or antigen-specific $\mathrm{T}$ cells.(79) Inflammasomes can contribute to tissue homeostasis, inflammation and immune responses to affect the formation,

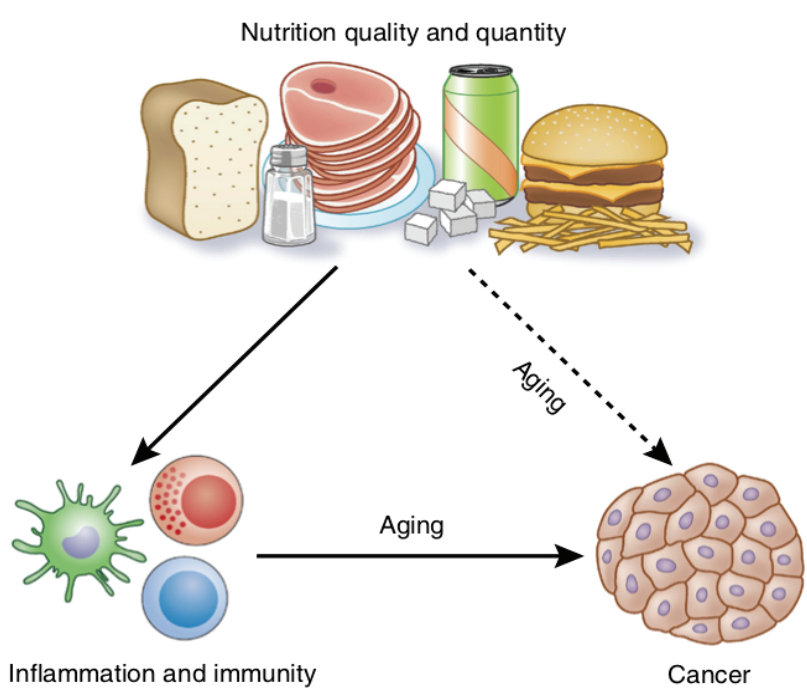

Figure 1. Relationships among nutrition, inflammation and immunity, and cancer.(25) (Adapted with permission from Springer Nature). 
progression and therapeutic response of cancer.(10) The contrasting roles of inflammasomes in the complex interplay between malignant cells and their niches operate at the cell-autonomous level. In inflammatory cells, caspase-1 activation can eliminate malignant precursors through programmed cell death and sterile inflammation and carcinogenesis, but contrarily in antigen-presenting cells stimulate anticancer immune responses and the production of trophic factors for cancer cells and their stroma. The inhibition of inflammasomes or their products neutralization, mainly interleukin (IL)-1 $\beta$ and IL-18, showed profound effects on carcinogenesis and tumor progression.(10)

Cancers derived from epithelial cells known as carcinomas while adenocarcinomas derived from epithelium in glandular tissues. They are heterogenous, consist not only cancer cells but also cancer-associated fibroblasts, different tumor-infiltrating immune cells, adipocytes, endothelial cells, pericytes and others. These cells secrete chemokines and cytokines $(26,27)$, affect cancer cells directly or promote cancer-associated inflammation by inducing immune cell infiltration thus lead to tumor initiation, progression, metastasis, but also have a role in cancer treatment. One of the most frequent immune cells involved are myeloid cells, including immature myeloid cells, neutrophils and macrophages, utilized as a cellular source for inflammasomes activation and secreting IL-1 $\beta$ and IL-18.(28) The etiological link between tumorigenesis and the chronic inflammation have been well documented in gastrointestinal (GI) tract cancers, where Helicobacter pylori infection associated with chronic gastritis, and colorectal cancer frequently associated with inflammatory bowel disease.(10,26,29). As inflammatory mediators, inflammasomes and their products also proved to be associated with GI cancers.

Oxidative stress mediated mechanisms in carcinogenesis in three stages: initiation, promotion, and progression. Oxidative stress leads to mutations in oncogenes and tumor-suppressor genes in the initiation stages. $(30,31)$ The 8-Hydroxy-20-deoxyguanosine (8-OHdG) elevation usually measured to observe oxidative stress-associated DNA-adduct in precancerous and cancerous tissues or cancer cell lines compare to normal tissue.(32-36) The 8-OHdG could induce GC to TA missense mutations, which will produce a transformed cell if they were escaping repair prior to DNA replication.(36) The formation of 8-OHdG DNA-adducts often related to tumor suppressor (TP53) and oncogene (KRAS) mutation observed in tobacco smoke-induced oxidative stress lungs.(37-39) Many clinical trials studying ROS and antioxidants in cancer showed controversial results, suggest that excessive ROS accumulation promotes severe cellular damage and triggers apoptosis including cancer cells, therefore cancer cells depend on an increased antioxidant capacity, which keeps ROS levels higher than in normal cells, but below a critical threshold able to maintain their viability. ROS limit distant metastasis: only cells with increased antioxidant capacity, or cells with adaptation to build up a powerful antioxidant response are able to succeed in their purpose to metastasize. $(4,5,40)$ Indeed, cancer initiation and progression has been linked to oxidative stress by increasing DNA mutations or inducing DNA damage, genome instability, and cell proliferation.(31)

The transcription factor nuclear factor erythroid 2 (NF-E2)-related factor 2 (Nrf2) belongs to the Cap ' $N$ ' Collar (CNC) family that contains a conserved basic leucine zipper (bZIP) structure. Nrf2 mainly function to activate the cellular antioxidant response to combat the harmful effects of extrinsic and intrinsic threats, such as xenobiotics and oxidative stress, make it traditionally regarded as the cell's main defense mechanism for survival, as seen in Figure 2. The dissociated Keap1 is ubiquitinated for proteasomal degradation, inducing Nrf2 translocates to the nucleus and binds to Maf to initiate transcription of antioxidant/ detoxification genes such as superoxide dismutase (SOD), heme oxygenase-1 (HMOX-1), nicotinamide adenine dinucleotide phosphate (NADPH): quinone oxidoreductase 1 (NQO1), and glutathione-s-transferases (GSTs) and combat the oxidative stress. Nrf2 defense response activation has been shown to protect against neurodegenerative diseases, aging, diabetes, photo-oxidative stress, cardiovascular disease, inflammation, pulmonary fibrosis, acute pulmonary injury, cancer, also against chemical carcinogen-induced tumor formation in the stomach, bladder and skin.(41-46) Contrarily, mice with single-nucleotide polymorphism (SNP) that reduced expression of Nrf2 are more susceptible to hyperoxia-induced lung damage, supporting the idea of protective role of Nrf2 against ROS and DNA damage in cells.(47-49)

Nrf2 activation has been noticed to protect against a variety of toxicants and diseases, yet its prolonged activation affecting on several types of cancer progression such as lung, breast, head and neck, ovarian, and endometrial carcinomas with clinically poor prognosis (50-52), partly due to Nrf2's ability to enhance cancer cell proliferation and promote chemoresistance and radioresistance, explaining why Nrf2 expression is induced during the course of drug resistance. (46) Oxidative stress can activate transcription factors such as nuclear factor-kappaB (NF-kB), activator protein 1 (AP1), $\mathrm{p} 53$, hypoxia-inducible factors (HIF)-1 $\alpha$, peroxisome 


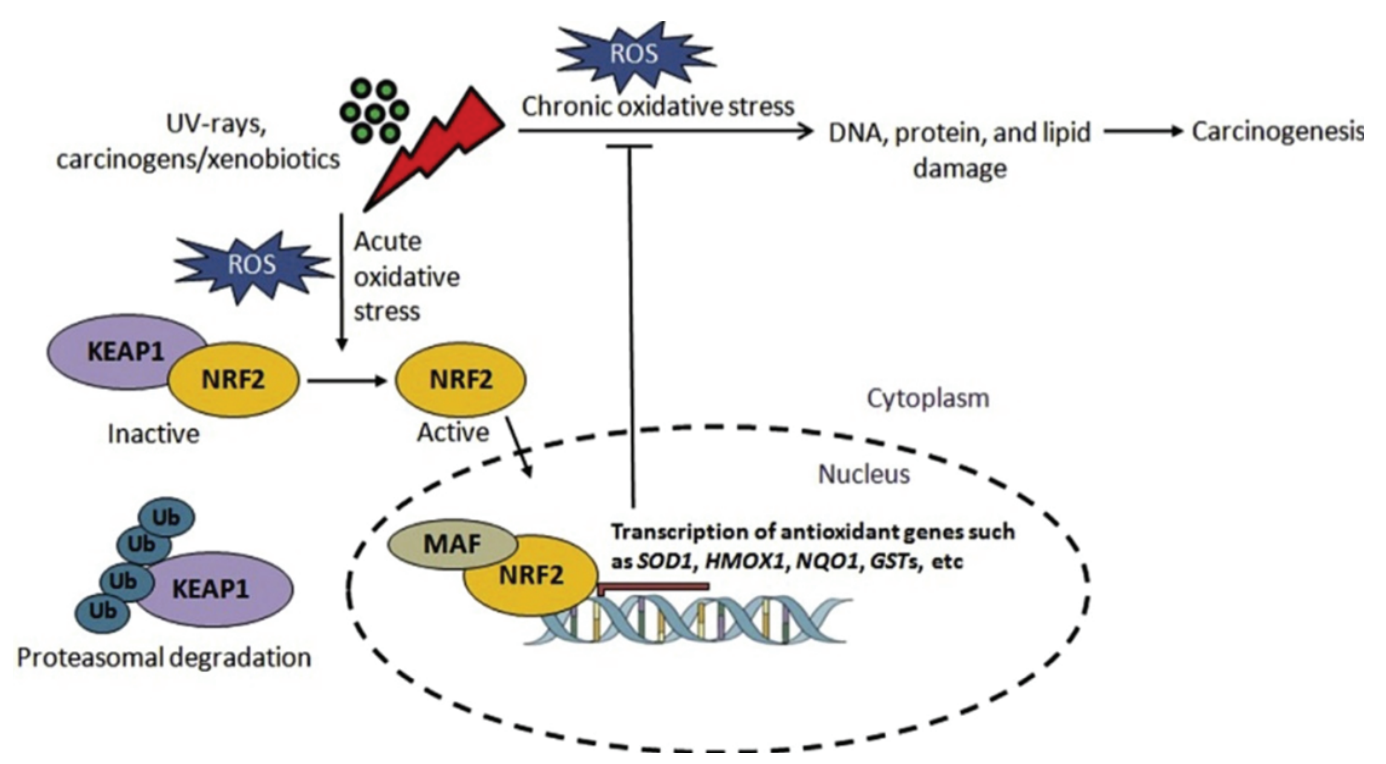

Figure 2. Activation of $\mathbf{N r f 2}$ in response to mild oxidative stress.(39) (Adapted with permission from Elsevier).

proliferator-activated receptors (PPAR)- $\gamma, \beta$-catenin/Wnt, and Nrf2, which lead to the expression of more than 500 genes including those for growth factors, inflammatory cytokines, chemokines, cell cycle regulatory molecules, and anti-inflammatory molecules. Overall, we could suggest that oxidative stress via chronic inflammation are closely link to transform normal cell to tumor cell, tumor cell survival, proliferation, chemoresistance, radioresistance, invasion, angiogenesis and stem cell survival.(31)

Obesity is a risk factor for cancer development and is associated with poor prognosis in multiple tumor types. The positive energy balance linked with obesity induces a variety of systemic changes including altered levels of insulin, insulin-like growth factor (IGF)-1, leptin, adiponectin, steroid hormones, and cytokines. Each of these factors alters the nutritional milieu and has the potential to create an environment that favors tumor initiation and progression.(2)

\section{Consumption of Red and Processed Meat, and Cancer}

Red meat is defined as flesh from mammals (pork, beef, lamb, veal, etc.), red when it is raw, due to a higher percentage of red muscle fiber than white.(53) Processed meat regards as preserved and flavored meat using methods such as salting, smoking, fermentation and curing.(13) Previous epidemiological and experimental studies associate red or processed meat consumption to colorectal carcinoma, and increased incidence of many other carcinomas such as oesophageal, gastric, breast, pancreas and lung.(54-56) The International IARC confirmed a sufficient evidence for an association between colorectal carcinoma and consumption of processed meat.(13) The 2007 panel also concluded that cancers of the esophagus, lung, pancreas, prostate, stomach, and endometrium may be linked to red and processed meat consumption; however, the evidence at the time was limited and inconsistent.(53)

GI cancers has a sporadic pattern, and arise in individual by cause of environmental rather than hereditary risk factors, with diet as the strongest contributor.(57) A high-fat diet increases bile acid secretion that is transformed by colonic microbiota into secondary bile acid with genotoxic properties of DNA damage due to ROS and nitric oxide synthase (NOS). $(58,59)$ Protein-rich diets produce inflammatory and toxic nitrogenous metabolites such as phenols, indoles, ammonia, and amines as results of microbial fermentation of undigested protein residues. (60) The nitrogenous metabolites which are well-known potential carcinogens and a prominent risk factor of GI cancer are nitrosamine and nitrosamide, formed by the reaction of nitrosating agents, such as nitrite and secondary amines and amides. They are potent alkylating agents that induce GC to AT transitions at the second base of codon 12 or 13 of the KRAS gene in the epithelial cells, then cause cancer development in the GI tract. $(61,62)$

Figure 3 explain some probable mechanisms on the association between red/processed meat and colorectal carcinomabring out heme, NOCs, heterocyclic amines (HCAs), N-glycolylneuraminic acid (Neu5Gc) and PAHs which were contained in the red and processed meat to be 


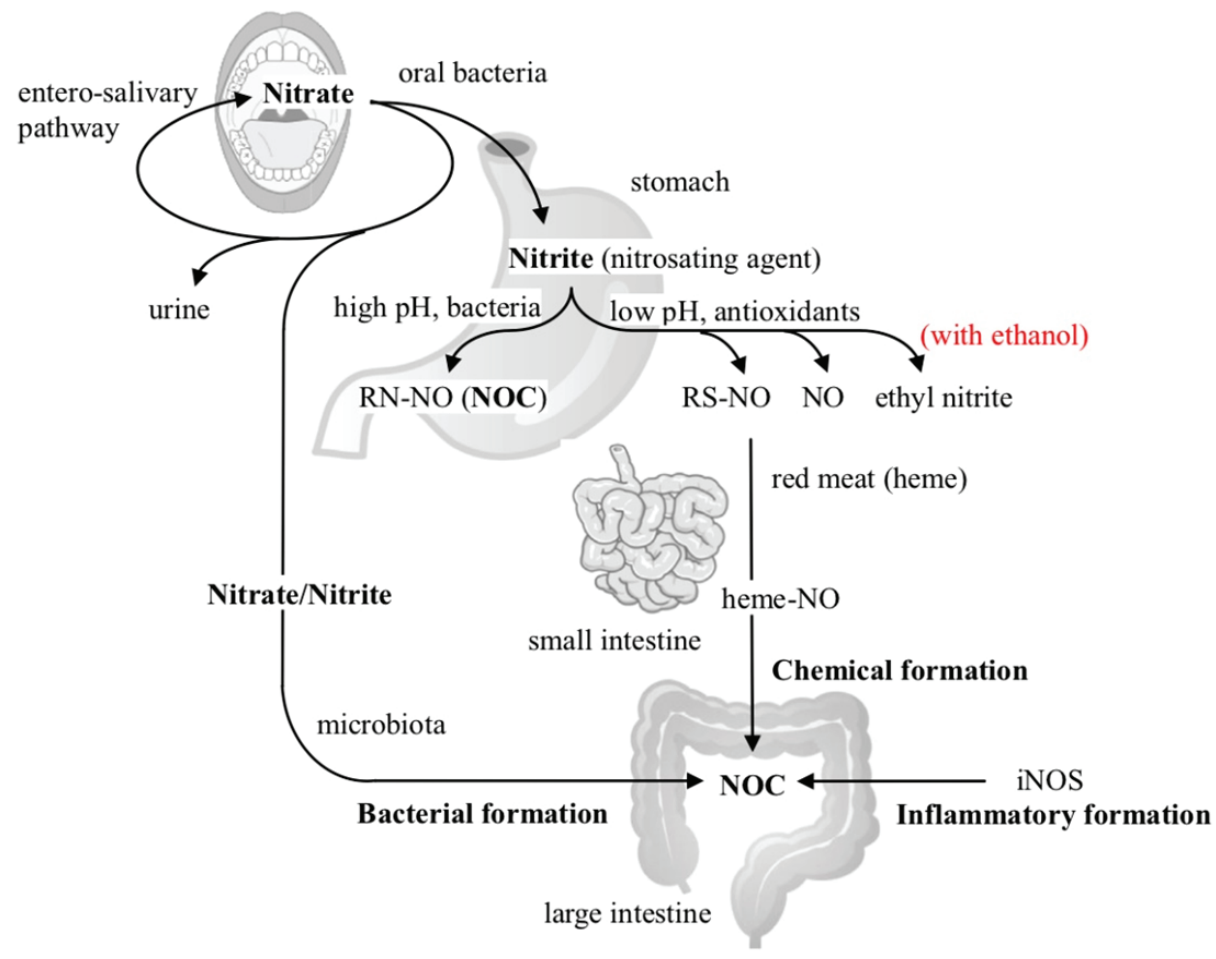

Figure 3. Proposed schema showing the metabolism of dietary nitrate/nitrite and NOC formation in the gastrointestinal tract.(55) (Adapted with permission from Elsevier). the carcinogenic mediators especially heme, although the exact mechanisms is still vague and controversial. Unless washed out by the gastric acid and antioxidant, red meat consumption can reach the lower intestine as precursors of nitrosating agents, together with bacterial formation from gut will modulate inflammation in the large intestine and by the time increased the cancer risk.(63) Multiple homeostatic signals especially Wnt signaling pathway regulate the homeostasis for normal colon epithelial architecture, the surface epithelial cells were controlled and well-balanced as well as new cells replacements from the crypts. $(64,65)$ The key genes involved were known upregulated high heme ingestion.(66) Another evidence showed that heme iron induce $\mathrm{G}>\mathrm{A}$ transition in adenomatous polyposis coli (APC) gene, rising $80 \%$ incident of the colon cancers considering APC is a tumor suppressor gene. $(67,68)$ After the mutations, $\beta$-catenin accumulates within colonic epithelial cells and gets translocated to the nucleus, forming a complex with DNA binding factor T-cell factor. Further, this will lead to transcription factors activation promoting uncontrolled cell proliferation of the colonic epithelial crypts.(68) TP53 and KRAS were also known to be mutated with the presence of high heme. Moreover, heme leads to free radical formation and generation of DNA adducts in colorectal epithelial cells via lipid peroxidation. Intestinalk dysbiosis will promote heme carcinogenic properties. Anyhow, a balanced diet containing green vegetables, olive oil and calcium may reduce the heme's carcinogenic effects.(69)
Chemoprevention: An Essential Approach to Controlling Cancer

Cancer can be defined as the dysregulated of cells proliferation. Many factors could induce cancers including environmental exposures (e.g., asbestos, ultraviolet radiation), lifestyle choices (tobacco, obesity, physical inactivity), infectious agents (e.g., human papillomavirus (HPV), human immunodeficiency virus (HIV), hepatitis $\mathrm{B}$ virus, Helicobacter pylori), and inherited conditions and mutations (e.g., familial adenomatous polyposis (FAP), hereditary nonpolyposis colorectal cancer, and the breast cancer (BRCA)1 and BRCA2). Chemoprevention termed as the use of drugs or other compounds to inhibit or reverse of the carcinogenic process.(70) Clinically, chemoprevention agents divided into three categories: primary chemoprevention (suited for they who may be at increased risk for disease), secondary chemoprevention (for patients with premalignant lesions that may progress to an invasive disease), and tertiary chemoprevention (to prevent recurrence or second primary cancers disease in those individuals who have already endured potentially curative therapy, such as treatment with aromatase inhibitors).(71) Current primary chemoprevention agents including nonsteroidal antiinflammatory drugs (NSAIDs) (e.g., aspirin, sulindac, celecoxib), vitamins and their derivatives (e.g., retinoids, selenium, vitamin $\mathrm{E}$ ), minerals 
(e.g., calcium), and plant extracts (e.g., wheat bran fiber, tea catechins, flavonoids, berry extracts, curcumin).(15)

The failure to control cancer deaths from common epithelial malignancies, such as those that occur in the lung, breast, prostate, colon, pancreas and ovary, provides the ultimate rationale for an approach based on prevention. The logical approach to controlling cancer is to prevent it before the complex series of genetic and epigenetic events that result in invasive and metastatic malignancy have occurred. (16) We need to refine our insights into early disease pathogenesis, together with enhanced screening for success risk assessment and any new risk models based on cellular and molecular insights.(15)

Cancer chemoprevention refers to the use of agents for the inhibition, delay, or reversal of carcinogenesis before invasion. At the molecular level, cancer chemoprevention intended for disruption or at least delay the multiple pathways and processes among the three stages of carcinogenesis: initiation, promotion, and progression. $(72,73)$ Chemopreventive agents are referred as blocking agents since they block mutagenic interactions with DNA, either permanently evading damaged DNA by inactivating or metabolizing carcinogens directly, acting as free-radical scavengers, or physiologically inducing anti-oxidative enzyme activity and triggering mechanisms of DNA repair. $(73,74)$ Blocking agents can also modify the epigenomic landscape.(75) In the present review, agents examined in the context of cancer chemoprevention are classified in four major categories, which are hormonal, medications, dietrelated agents, and vaccines.(14) Because chemoprevention refers to the wide-spread and long-term use of compounds by the general healthy population, safety is an issue of paramount importance that needs to be addressed in studies with long follow-up in large segments of the population in order to be able to identify even rare side effects.(14) Chemoprevention will have to be taken for years, so ideally it should has little or no toxicity, with high efficacy in multiple sites, can be taken orally, low cost, and the mechanism of action is known.(18)

On the contrary, suppressing agents refer to compounds that affect later stages of carcinogenesis (promotion and progression) by decreasing the proliferative capacity of initiated cells.(73) They hinder the proliferation of cancer cell by down-regulating signal transduction pathways such as NF- $\kappa \mathrm{B}$, mammalian target of rapamycin (mTOR), signal transducer and activator of transcription 3 (STAT-3), and many others (76-79), also by restraining enzymes that modulate signal transduction to hormone responsive elements such as cytochrome P450 (80). Suppressing agents are also likely to promote apoptosis pathways while inhibiting the angiogenesis, epithelial mesenchymal transition, invasion, and dissemination pathways thus reduce or delay the cells metastatic evolving ability, therefore decreasing the cancer mortality.(74,79-81)

Based on epidemiological studies that people have lower incidence of cancer when they consume diet richer in fruits and vegetables, several chemoprevention molecules derived from spices, teas, fruits and vegetables including lemon, saffron, garlic, broccoli, pomegranate, berries, and others, suggested this happening due to all possible vitamins and other micronutrients, especially the antioxidant ones, such as vitamin $\mathrm{A}, \mathrm{C}$, and $\mathrm{E}$, omega-3 fatty acids, and folate as in mediteranian diet.(39) Curcumin and green tea derived molecules showed their ability to stabilize $\mathrm{I} \kappa \mathrm{B}$, the cytoplasmic inhibitor of NF- $\kappa \mathrm{B}$, so it cannot be translocated to the nucleus to act as a pro-inflammatory molecule, as we know that chronic inflammation associated with tumor progression as its role in ROS formation, lead to DNA alteration, promote several genes involved in cell proliferation for example via NF- $\mathrm{KB} .(82,83)$

Oxidative stress is not the only one to promote transcription factors which express the enzymes for free radical scavenging but also some phytochemicals including sulphoraphane and resveratrol, derived from cruciferous vegetables such as broccoli and grapes in order. Nrf2, one transcription factor that acts as cell's most important regulator of antioxidant defenses, binds to cis-enhancer sequences called antioxidant responsive elements that are 5 'flanking of the promoter regions for genes encoding detoxifying and antioxidant enzymes, such as GST and NADPH:NQO1.(46,84,85)

Some phytochemical such as resveratrol, apigenin, curcumin, fisetin, quercetin, 6-gingerol, and piperlonguminine can either induce apoptosis or cell death through autophagy by different mechanisms.(86) Other studies exploit some phytochemicals to inhibit metastasis generation of tumor cells via epithelial mesenchymal transition. It was also found that silibinin, curcumin, green tea derived compounds, 6-gingerol, and resveratrol could inhibit matrix metalloproteinases (MMPs) expression, especially MMP-9, and in other side increasing E-cadherin molecule, that maintain the cells to keep attached each other, make it more challenging for them to migrate in adjacent tissue invasion.(87-89) Some phytochemicals supplement such as Protandim (Bacopa monniera, Camellia sinensis, Curcuma longa, Silybum marianum, and Withania somnifera) showed to be a potent activator of Nrf2 in both cell culture and animal models $(74,90,91)$, 
while many are also known to inhibit the conversion of procarcinogens to their electrophilic (DNA damaging) species (17).

Current studies showed that epigenetic was importantly involved in the progression of cancer as found in Table 1. Several epigenetic mechanisms relating to nucleosome organization including DNA methylation, histone post-translational modifications, such as methylation, acetylation, phosphorylation and nucleosomes occupancy dynamics have been described to be altered during cancer development.(92-94) They are potentially reversible count on environmental fluctuation such as nutrition, oxidative stress, pollution, inflammation, and life style. $(93,95)$ Therefore, epigenetic give a potential approach for cancer therapy. Currently, FDA approved the DNA methyltransferase (DNMT) inhibitors 5-azacytidine (5-

Table 1. Mechanism of action of the different bioactive compounds on epigenetic alterations.(18) (Adapted with permission from Frontiers Media).

\begin{tabular}{|c|c|c|c|}
\hline Mechanism of action & Neoplasia & Study type & Target genes \\
\hline \multicolumn{4}{|l|}{ ISOFLAVONES } \\
\hline Decreased methylation & Breast cancer & In vitro & $\begin{array}{l}\text { BRCA1, BRCA2, ATM, APC, PTEN; } \\
\text { SERPINB5 }\end{array}$ \\
\hline Increased acetylation & Breast cancer & $\begin{array}{l}\text { Preclinical studies: in vitro and } \\
\text { in vivo }\end{array}$ & $\mathrm{ER} \alpha$ \\
\hline $\begin{array}{l}\text { Increased active mark } \mathrm{H} 3 \mathrm{~K} 4 \text { and } \\
\text { acetylation }\end{array}$ & Breast cancer & In vitro and in vivo (xenografts) & p16 ${ }^{\text {INK4a; }} ;$ p21 WAF1 \\
\hline Increased repressive mark H3K27 & Uterine leiomyomas & Human & $\mathrm{p} 16^{\mathrm{INK} 4 \mathrm{a}} ; \mathrm{p} 21^{\text {WAF1 }}$ \\
\hline $\begin{array}{l}\text { Increased acetylation, decreased } \\
\text { methylation and increased active mark } \\
\text { H3K4 }\end{array}$ & Prostate cancer & In vitro & $\begin{array}{l}\text { p16 }{ }^{\text {INK4a; }} ;{ }^{21}{ }^{\text {WAF1 }}, \text { BTG3, AKT, } \\
\text { CYLD }\end{array}$ \\
\hline \multicolumn{4}{|l|}{ EPIGALLOCATECHIN GALLATE } \\
\hline Decreased methylation & Breast, colorectal and skin cancer & In vitro & $\begin{array}{l}\text { p16 INK4a; p21 WAF1 }, \text { RAR } \beta, \text { RXR } \alpha \\
\text { MGMT, MLH1 }\end{array}$ \\
\hline Decreased methylation & Oral squamous carcinoma & In vitro & RECK \\
\hline Increased tumor suppressor miR & Hepatocarcinoma & In vitro & BCL-2 \\
\hline Decreased oncomir & NSCLC & In vivo & p53 \\
\hline \multicolumn{4}{|l|}{ RESVERATROL } \\
\hline Decreased oncomiRs & Colorectal cancer & In vitro & TGF $\beta 1$ \\
\hline Incresead methylation & Breast cancer & In vitro & $\begin{array}{l}\text { AURKA } \\
\text { PLK1 }\end{array}$ \\
\hline Increased tumor suppressor miRs & Colorectal cancer & In vitro & E2F3 \\
\hline Hyperacetylation & Breast cancer & In vivo & BRCA1 \\
\hline \multicolumn{4}{|l|}{ SULFORAPHANE } \\
\hline Hyperacetylation & Colorectal and prostate cancer & $\begin{array}{l}\text { In vitro } \\
\text { In vivo }\end{array}$ & $\begin{array}{l}\text { BAX } \\
\text { p21 }\end{array}$ \\
\hline Hyperacetylation & Breast cancer & In vitro & $\begin{array}{l}\text { Caspases } \\
\text { Cytochrome c }\end{array}$ \\
\hline Decreased methylation & Breast and prostate cancer & In vitro & $\begin{array}{l}\text { PTEN } \\
\text { RAR } \beta 2\end{array}$ \\
\hline $\begin{array}{l}\text { Hyperacetylation } \\
\text { Decreased repressive mark }\end{array}$ & Breast cancer & In vivo & hTERT \\
\hline \multicolumn{4}{|l|}{ CURCUMIN } \\
\hline Decreased methylation & Colorectal cancer & In vitro & $\mathrm{NF}-\kappa \mathrm{B}$ pathway \\
\hline Decreased methylation & Cervical cancer & In vitro & RAR $\beta 2$ \\
\hline Decreased methylation & Myeloid leukemia & $\begin{array}{l}\text { In vitro } \\
\text { In vivo }\end{array}$ & $\left.\mathrm{p} 15\right|^{\mathrm{NK} 4 \mathrm{~B}}$ \\
\hline $\begin{array}{l}\text { Increased suppressor miRs } \\
\text { Decreased oncomiRs }\end{array}$ & Colorectal cancer & In vitro & $\begin{array}{l}\text { Cyclin D1 and E1 } \\
\text { CDK4 and } 6 \\
\text { cMYC }\end{array}$ \\
\hline $\begin{array}{l}\text { Increased suppressor miRs } \\
\text { Decreased oncomiRs }\end{array}$ & Melanoma & In vivo & $\begin{array}{l}\text { BCL-2 } \\
\text { PCNA }\end{array}$ \\
\hline Increased suppressor miRs & Pancreatic carcinoma & In vivo & $\begin{array}{l}\text { Notch1 } \\
\text { MMp-9 }\end{array}$ \\
\hline
\end{tabular}


AZA) and 2'-deoxy-5-azacytidine (DAC) for the treatment of myelodysplasia myelodysplastic syndrome (MDS), a preleukemic syndrome and myelomonocytic leukemia, and the results are promising too for solid tumor therapy. $(92,96,97)$ Epigenetics complementing the chemoprevention mechanisms, opening up the possibilities for new molecules findings, particularly to prevent the disease and reach a better quality of life.(16)

\section{Cruciferous Vegetable Intake and Risk of Cancer}

Mostly healthy diets against chronic diseases including cancer recommend to increase vegetables and fruits consumption, as many growing evidences support that fruits and vegetables might be beneficial in cancer prevention. $(98,99)$ Cruciferous vegetables specifically, named for their cross-shaped flowers, including cabbage, broccoli, brussel's sprouts, cauliflower and other members of the family, contain many nutrients with cancer-fighting properties. (100) Present meta-analysis studies representing a pooled total of 18,673 cases summarized the inverse associations between cruciferous vegetables consumption with risk of lung, colorectal, stomach, breast, prostate, and other cancers. (101-111) About 200-250 g/day broccoli consumption for 10 days has been showed to decrease tobacco smokeinduced DNA damage in smokers. $(112,113)$

The protective effect of cruciferous vegetables on breast cancer is biologically conceivable if we look deeper into their key components. Glucosinolates, the precursors of isothiocyanates (ITCs) and indole-3-carbinol believed to have anticancer properties, are especially rich in cruciferous vegetables.(107) Previous study screened the extract of cruciferous vegetables and found that sulphoraphane [1-isothiocyanato-4-(methylsulfinyl) butane].(85) A phytochemical belonging to a large chemical family of isothiocyanates, a potent antioxidant involving Nrf2 signaling and Aryl hydrocarbon receptor (Ahr) pathway.(114) By inhibition of phase I activating enzymes (e.g., cytochrome $\mathrm{P} 450$ (CYP)1A1 and CYP1A2), inhibits CYP1B1 in MCF10A cells (115), inhibits CYP3A4 in human hepatocytes (116). Induction of phase II detoxifying enzymes, such as GSTs, ITCs may protect cells against cancer initiation by neutralizing endogenous and exogenous electrophiles in breast tissue.(108,109) While indole-3carbinol induce 2-hydroxylation of estradiol, resulting in nonestrogenic metabolites (110), binding to the estrogen receptor (ER) thus downregulates the ER signaling and prevent the development of estrogen-related cancers including breast, endometrial and cervical cancers. $(102,111)$ Interestingly, the inverse association seems to be stronger for advanced stages of cancer. Current studies on isothiocyanates, including phenethyl isothiocyanate and sulforaphane, with addition of other chemicals from the same vegetables such as 3,3'-diindolylmethane, have been shown to inhibit prostate cancer cell growth and induction of apoptosis in vitro and in vivo by repression of androgen receptor and induction of endogenous cyclin-dependent kinase.(117-119)

\section{Cruciferous Vegetable Intake and Risk of Cancer}

In modern advances of medical technology worldwide, in fact cancer cases keep growing.(120) Diet and exercises were known to significantly impact this prevalence, renewing interest in dietary phytochemical research, especially those including polyphenols, alkaloids, carotenoids, and nitrogen compounds.(121-124) These groups of phytochemicals showed the ability to affect cell proliferation and cell cycle regulation, involve in multiple signaling pathways that are often disrupted in tumor initiation, proliferation and propagation.(17,124-127)

Carcinogenesis is a multistep process transforming a cell in its molecular level to undergo uncontrolled cellular division.(128) For the last fifty years, many research found innumerable critical molecular players and targeted pathways, which activate proto-oncogenes and inactivation of tumor suppressor genes, therefore cells represented tumor initiation, promotion and progression. $(129,130)$ At initiation, after exposure to a carcinogenic agent, tumor cells start in a rapid and irreversible process, followed by its distribution and transportation to tissues causing nonlethal mutations in cellular DNA. The accumulation of this selective clonal initiated cells will add irreversible genetic changes which persist with each new cycle of proliferation.(130)

Tumor promotion, in contrast, is a relatively lengthy and reversible process where actively proliferating preneoplastic cells begin to divide and multiply as seen in Figure 4.(131) Tumor progression, as the final stage, occurs after the mutations has reached an invasive cellular phenotype with metastatic potential.(130,132) Either dietary- and non-dietary-derived phytochemicals (molecules found in plants) cancer chemoprevention focusing on finding natural agents that specifically impact the earliest prevention of 


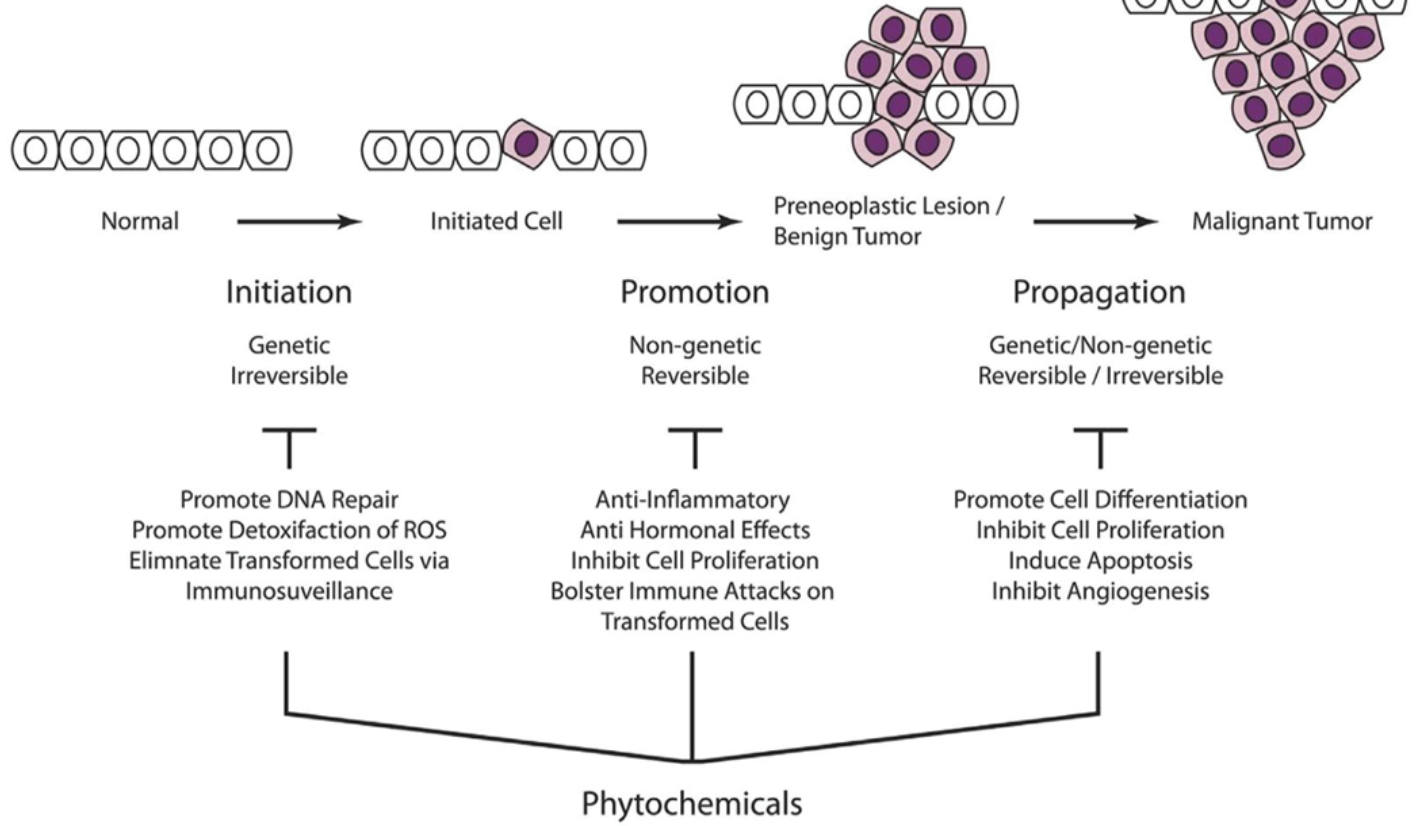

Figure 4. Carcinogenesis is a multistep process that ultimately reprogram a normal cell into a cancer cell.(131) Adapted with permission from Impact Journals).

cellular transformation (protecting DNA from mutation) by modulation of cytoprotective enzyme activation. (74,79,133-137) For example, phytochemicals agent that prevent carcinogens to reach its targeted sites, and at once support detoxification of highly reactive molecules. (134) Phytochemicals also enhance innate immune surveillance to eliminate transformed cells.(135) Finally, phytochemicals improve DNA repair mechanisms, tumor suppressors and inhibit cellular proliferation pathways.(133137) As a primary chemoprevention, some phytochemicals appear to alter the epigenome and reverse abnormal gene expression through modulation of DNMTs, methyl binding proteins (MBDs), histone deacetylases (HDACs), micro RNAs (miRNAs), and several other epigenetic mechanisms. Thus, phytochemicals promote genomic integrity and cellular homeostasis in both in vitro and in vivo models.(75)

Natural agents have emerged as novel therapeutic agents of drug-repositioning to influence autophagic activity.(138) Table 2 describes some natural agents and their mechanisms in cancer. Several natural agents modulate autophagy. For example, tanshinone IIA (139), ursolic acid (140), quercetin (141), fisetin (142), resveratrol (143), and honokiol (144) act as inhibitors of the AKT/ mTOR pathway. Tanshinone IIA modulates the initiation of phagophore formation. Ginsensoside (145) and ursolic acid (146) affect the formation of autophagosomes. Ginsenoside RO inhibits autophagosome-lysosome fusion.(147) Curcumin, or turmeric (bis- $\alpha, \beta$-unsaturated $\beta$-diketone), is a goldcolored spice widely used in Indian cooking, textile dyes, and in traditional Ayurvedic medicine I, contain polyphenol derived from the roots of the perennial Curcuma longa plant. Curcumin inhibits the growth of a variety of cell lines in vitro, by affecting the cell cycle arrest and apoptosis, specifically by modulating NF- $\mathrm{B}$, cyclooxygenase- 2 (COX-2), tumor necrosis factor alpha (TNF- $\alpha$ ), STAT-3 and cyclin D1.(148-151)

Resveratrol is a phytoalexin found in many fruits and plants including red wine, grapes, berries and peanuts. (152) Highest levels of resveratrol found in the roots of the Polygonum cuspidatum, or Japanese knotweed, which is traditionally used as Chinese medicinal treatments for dermatitis, bacterial infections and inflammation. Previous studies identified the anti-cancer properties of resveratrol against several different tumor types in multiple stages. At higher dose, resveratrol could induce apoptosis and studies in rats showed resveratrol mediates a down-regulation of androgen receptor expression and suppression of androgen responsive glandular kallikrein, an orthologue of the human prostate specific antigen.(153-158) Another effects of resveratrol may be achieved through promoting innate immune system immunosurveillance and therefore enhancing elimination of spontaneous tumor cells prior to proliferation.(131) 
Table 2. Some natural agents' chemo-preventive mechanism.

\begin{tabular}{|c|c|c|}
\hline Natural Agents & Cancer Preventing Mechanis ms & References \\
\hline $\begin{array}{l}\text { Tanshinone IIA, ursolic acid, quercerin, } \\
\text { fisetin, resveratrol and honokiol }\end{array}$ & Inhibitors of the AKT/mTOR pathway & $(139-144)$ \\
\hline Tanshinone IIA & Modulates the initiation of phagophore formation & (139) \\
\hline Ginsensoside and ursolic acid & Affect the formation of autophagosomes & $(145,146)$ \\
\hline Ginsenoside Ro & Inhibits autophagosome-lysosome fusion & $(147)$ \\
\hline $\begin{array}{l}\text { Curcumin, or turmeric (bis- } \alpha, \beta- \\
\text { unsaturated } \beta \text {-diketone) }\end{array}$ & $\begin{array}{l}\text { Inhibits the growth of a variety of cell lines in vitro, by affecting the cell } \\
\text { cycle arrest and apoptosis, specifically by modulating } \\
\mathrm{NF}-\kappa \mathrm{B}, \mathrm{COX}-2, \mathrm{TNF}-\alpha, \text { STAT- } 3 \text { and cyclin D } 1\end{array}$ & $(148-151)$ \\
\hline Resveratrol & Induce apoptosis, promoting innate immune system immunosurveillance & $(153-158)$ \\
\hline Epigallocatechin-3-gallate (EGCG) & $\begin{array}{l}\text { Induce apoptosis and inhibit tumor cell growth, inhibit angiogenesis, } \\
\text { modulating the immune system, and activating enzyme systems involved } \\
\text { in cellular detoxification through the glutathione S-transferase and } \\
\text { quinone reductase pathways }\end{array}$ & $(161,162)$ \\
\hline $\begin{array}{l}\text { Lycopene, beta carotene, Vitamins A, } \\
\text { C, E, selenium }\end{array}$ & Prevent inflammation, preventing cellular damage induced by free ROS & $(163)$ \\
\hline $\begin{array}{l}\text { Folate, or folacin, pteroylglutamic acid } \\
\text { or vitamin B9 }\end{array}$ & $\begin{array}{l}\text { Roles as a cofactor in carbon transfer reactions essential in DNA } \\
\text { synthesis, repair and methylation }\end{array}$ & $(164)$ \\
\hline Apigenin (4',5,7-trihydroxyflavone) & $\begin{array}{l}\text { Promoting cell cycle arrest and enhance apoptosis in cancer cells and } \\
\text { xenograft models, downregulate NF- } \kappa \text { B activity through the } \\
\text { suppression of phosphorylation of } p 65 \text {, and Akt signaling, regulating } \\
\text { Bcl- } 2 \text {, cyclin D1, cyclooxygenase- } 2 \text {, MMP-9 and NOS- } 2 \text { expression } \\
\text { in prostate carcinoma. }\end{array}$ & $(175-177,180)$ \\
\hline
\end{tabular}

Camellia sinensis, or tea, known as the most ancient and popular beverages consumed around the world. Different species of tea contains some combination of polyphenols, alkaloids, minerals, and other volatile organic compounds. (159) Epigallocatechin-3-gallate (EGCG) and Epicatechin3-gallate (ECG) found in a very high level in tea, especially higher in green tea.(160) Catechin polyphenols perform a strong antioxidant activity and thought to be able to prevent specific DNA damage by ROS, thereby preventing tumor mutagenesis of normal cells. $(161,162)$ Tea polyphenols in pre-clinical studies showed to induce apoptosis and inhibit tumor cell growth, inhibit angiogenesis, modulating the immune system, and activating enzyme systems involved in cellular detoxification through the GST and quinone reductase pathways. $(161,162)$

Endogenous antioxidants naturally produced in our body help to neutralize ROS, while external sources of antioxidants obtained from fruits, vegetables and grains.(129) Lycopene, beta carotene, Vitamins A, C, E, selenium and other dietary antioxidants known to prevent inflammation, preventing cellular damage induced by free ROS, thus slow the cancer development.(163)

Folate, or folacin, pteroylglutamic acid or vitamin B9, is a water-solute B-vitamin. Folate roles as a cofactor in carbon transfer reactions essential in DNA synthesis, repair and methylation.(164) Humans can not synthesize folates de novo, so we take folic acid supplements. Large prospective studies showed $\sim 25 \%$ reduction in colorectal cancer risk in subjects who takes high folate compared to ones with lower intake (165), and a meta analysis study reported a significant reduction in breast cancer risk in women who take higher folate in their diet although no correlation was found between circulating folate level and breast cancer risk (166).

Lycopene is a natural carotenoid found in many fruits and vegetables especially in tomatoes and its derivative products.(167) Recent studies showed that lycopene involved in antioxidant reactions including SOD-1 and GST-omega-1 thus downregulate ROS expression, and ROS generating proteins.(168) Another study pointed lycopene 
to inhibit cell proliferation, induce apoptosis, and attenuate the metastatic capacity of prostate cancer cells $(169,170)$, as supported by the data that linked increased consumption of lycopene-rich food with lower prostate cancer risks (170-172).

Apigenin (4',5,7-trihydroxyflavone), also abundant in fruits and vegetables, is a kind of flavonoid with a broad spectrum of anti-proliferative activities against many cancer cells. $(173,174)$ Several proposed mechanisms of apigenin reported its role in promoting cell cycle arrest and enhance apoptosis in cancer cells and xenograft models $(175,176)$, downregulate NF- $\mathrm{KB}$ activity through the suppression of phosphorylation of p65 (177), and Akt signaling (178179). Apigenin exerted potent chemopreventive activities through regulating B-cell lymphoma 2 (BCL-2), cyclin D1, cyclooxygenase-2, MMP-9 and NOS-2 expression in prostate carcinoma.(180)

\section{Conclusion}

Many studies provide the role of red meat and processed meat in colorectal, esophagus, liver, kidney, and prostate cancer, which etiology mechanisms suggested by means of HCAs, polycyclic PAHs, NOCs, and heme iron. On the contrary, several dietary agents clearly shown to have anticancer properties and contribute as one variable affecting the cancer prevalence. However, understanding how these dietary agents interact with cancer cells, the immune system and oxidative stress pathways may one day expose a way of safe, pleasant, non-toxic and economical anti-cancer therapeutics.

\section{References}

1. Hanahan D, Weinberg RA. The hallmarks of cancer. Cell. 2000; 100: 57-70.

2. Hopkins BD, Concalves MD, Cantley LC. Obesity and cancer mechanisms: cancer metabolism. J Clin Oncol. 2016; 34: 4277-83.

3. Font-Burgada J, Sun B, Karin M. Obesity and Cancer: The Oil that Feeds the Flame. Cell Metab 2016; 23: 48-62.

4. Piskounova E, Agathocleous M, Murphy MM, Hu Z, Huddlestun SE, Zhao Z, et al. Oxidative stress inhibits distant metastasis by human melanoma cells. Nature. 2015; 527: 186-91.

5. Peiris-Pagés M, Martinez-Outschoorn UE, Sotgia F, Lisanti MP. Metastasis and oxidative stress: are antioxidants a metabolic driver of progression? Cell Metab. 2015; 22: 956-8.

6. Hanahan D, Weinberg RA. Hallmarks of cancer: the next generation. Cell. 2011; 144: 646-74.

7. Franchi L, Muñoz-Planillo R, Núñez G. Sensing and reacting to microbes through the inflammasomes. Nat Immunol. 2012; 13: 32532.
8. Wen H, Ting JPY, O'Neill LAJ. A role for the NLRP3 inflammasome in metabolic diseases-did Warburg miss inflammation? Nat Immunol. 2012; 13: 352-7.

9. Rathinam VAK, Vanaja SK, Fitzgerald KA. Regulation of inflammasome signaling. Nat Immunol. 2012; 13: 333-42.

10. Zitvogel L, Kepp O, Galluzzi L, Kroemer G. Inflammasomes in carcinogenesis and anticancer immune responses. Nat Immunol. 2012; 13: 343-51.

11. Alaejos MS, Afonso AM. Factors that affect the content of heterocyclic aromatic amines in foods. Comp Rev Food Sci Food Safe. 2011; 10: 52-108.

12. Alomirah H, Al-Zenki S, Al-Hooti S, Zaghloul S, Sawaya W, Ahmed $\mathrm{N}$, et al. Concentrations and dietary exposure to polycyclic aromatic hydrocarbons (PAHs) from grilled and smoked foods. Food Control. 2011; 22: 2028-35.

13. Bouvard V, Loomis D, Guyton KZ, Grosse Y, El Ghissassi F, Benbrahim-Tallaa L, et al. Carcinogenicity of consumption of red and processed meat. Lancet Oncol. 2015; 115: 1599-600.

14. Benetou V, Lagiou A, Lagiou P. Chemoprevention of cancer: current evidence and future prospects. F1000Res. 2015; 4: 916. doi: 10.12688/f1000research.6684.1.

15. Patterson SL, Colbert Maresso K, Hawk E. Cancer chemoprevention: successes and failures. Clin Chem. 2013; 59: 94-101.

16. Sporn MB, Suh N. Chemoprevention: an essential approach to controlling cancer. Nat Rev Cancer. 2002; 2: 537-43.

17. Surh YJ. Cancer chemoprevention with dietary phytochemicals. Nat Rev Cancer. 2003; 3: 768-80.

18. De Melo FHM, Oliveira JS, Sartorelli VOB, Montor WR. Cancer chemoprevention: classic and epigenetic mechanisms inhibiting tumorigenesis. What have we learned so far? Front Oncol. 2018; 8 : 644. doi: 10.3389/fonc.2018.00644.

19. Coussens LM, Werb Z. Inflammation and cancer. Nature. 2002; 420: 860-7.

20. Mantovani A. Cancer: inflammation by remote control. Nature. 2005; 435: 752-3.

21. Schäfer M, Werner S. Cancer as an overhealing wound: an old hypothesis revisited. Nat Rev Mol Cell Biol. 2008; 9: 628-38.

22. Nathan C, Cunningham-Bussel A. Beyond oxidative stress: an immunologist's guide to reactive oxygen species. Nat Rev Immunol. 2013; 13: 349-61.

23. Shivappa N, Steck SE, Hurley TG, Hussey JR, Hébert JR. Designing and developing a literature-derived, population-based dietary inflammatory index. Public Health Nutr. 2013; 17: 1689-96.

24. Prieto I, Montemuiño S, Luna J, de Torres MV, Amaya E. The role of immunonutritional support in cancer treatment: current evidence. Clin Nutr. 2017; 36: 1457-64.

25. Zitvogel L, Pietrocola F, Kroemer G. Nutrition, inflammation and cancer. Nat Immunol. 2012; 18: 843-50.

26. Grivennikov SI, Greten FR, Karin M. Immunity, inflammation, and cancer. Cell. 2010; 140: 883-99.

27. Coussens LM, Zitvogel L, Palucka AK. Neutralizing tumor-promoting chronic inflammation: a magic bullet? Science. 2013; 339: 286-91.

28. Kolb R, Liu GH, Janowski AM, Sutterwala FS, Zhang W. Inflammasomes in cancer: a double-edged sword. Protein Cell. 2014; 5: 12-20.

29. Ferrone C, Dranoff G. Dual roles for immunity in gastrointestinal cancers. J Clin Oncol. 2010; 28: 4045-51.

30. Toyokuni S. Novel aspects of oxidative stress-associated carcinogenesis. Antioxid Redox Signal. 2010; 28: 1373-7.

31. Reuter S, Gupta SC, Chaturvedi MM, Aggarwal BB. Oxidative stress, inflammation, and cancer: How are they linked? Free Radic Biol Med. 2010; 49: 1603-16. 
32. Kubo N, Morita M, Nakashima Y, Kitao H, Egashira A, Saeki $\mathrm{H}$, et al. Oxidative DNA damage in human esophageal cancer: clinicopathological analysis of 8-hydroxydeoxyguanosine and its repair enzyme. Dis Esophagus. 2013; 27: 285-93.

33. Matsui A, Ikeda T, Enomoto K, Hosoda K, Nakashima H, Omae K, et al. Increased formation of oxidative DNA damage, 8-hydroxy2'-deoxyguanosine, in human breast cancer tissue and its relationship to GSTP1 and COMT genotypes. Cancer Lett. 2000; 151: 87-95.

34. Dziaman T, Huzarski T, Gackowski D, Rozalski R, Siomek A, Szpila A, et al. Elevated level of 8-oxo-7,8-dihydro-2'-deoxyguanosine in leukocytes of BRCA1 mutation carriers compared to healthy controls. Int J Cancer. 2009; 125: 2209-13.

35. Borrego S, Vazquez A, Dasí F, Cerdá C, Iradi A, Tormos C, et al. Oxidative stress and DNA damage in human gastric carcinoma: 8-Oxo-7'8-dihydro-2'-deoxyguanosine (8-oxo-dG) as a possible tumor marker. Int J Mol Sci. 2013; 14: 3467-86.

36. Wang M, Abbruzzese JL, Friess H, Hittelman WN, Evans DB, Abbruzzese MC, et al. DNA adducts in human pancreatic tissues and their potential role in carcinogenesis. Cancer Res. 1998; 58: $38-41$.

37. Rivlin N, Brosh R, Oren M, Rotter V. Mutations in the p53 tumor suppressor gene: important milestones at the various steps of tumorigenesis. Genes Cancer. 2011; 2: 466-74.

38. Le Calvez F, Mukeria A, Hunt JD, Kelm O, Hung RJ, Tanière P, et al. TP53 and KRAS mutation load and types in lung cancers in relation to tobacco smoke: distinct patterns in never, former, and current smokers. Cancer Res. 2005; 65: 5076-83.

39. Chikara S, Nagaprashantha LD, Singhal J, Horne D, Awasthi S, Singhal SS. Oxidative stress and dietary phytochemicals: Role in cancer chemoprevention and treatment. Cancer Lett 2018; 413: 122-34.

40. Gorrini C, Harris IS, Mak TW. Modulation of oxidative stress as an anticancer strategy. Nat Rev Drug Discov. 2013; 12: 931-47.

41. Motohashi H, Yamamoto M. Nrf2-Keap1 defines a physiologically important stress response mechanism. Trends Mol Med. 2004; 10: 549-57.

42. Jeong WS, Jun M, Kong AN. Nrf2: A potential molecular target for cancer chemoprevention by natural compounds. Antioxid Redox Signal. 2006; 8: 99-106.

43. Zhang DD. Mechanistic studies of the Nrf2-Keap1 signaling pathway. Drug Metab Rev. 2006; 38: 769-89.

44. Kensler TW, Wakabayashi N, Biswal S. Cell survival responses to environmental stresses via the Keap1-Nrf2- ARE pathway. Annu Rev Pharmacol Toxicol. 2007; 47: 89-116.

45. Lau A, Villeneuve NF, Sun Z, Wong PK, Zhang DD. Dual roles of Nrf2 in cancer. Pharmacol Res. 2008; 58: 262-70.

46. Jaramilo MC, Zhang DD. The emerging role of the Nrf2-Keap1 signaling pathway in cancer. Genes Dev. 2013; 27: 2179-91.

47. Hirayama A, Yoh K, Nagase S, Ueda A, Itoh K, Morito N, et al. EPR imaging of reducing activity in Nrf2 transcriptional factor-deficient mice. Free Radic Biol Med. 2003; 34: 1236-42.

48. Morito N, Yoh K, Itoh K, Hirayama A, Koyama A, Yamamoto M, et al. Nrf2 regulates the sensitivity of death receptor signals by affecting intracellular glutathione levels. Oncogene. 2003; 22: 9275-81.

49. Cho HY, Jedlicka AE, Reddy SP, Kensler TW, Yamamoto M, Zhang LY, et al. Role of NRF2 in protection against hyperoxic lung injury in mice. Am J Respir Cell Mol Biol. 2002; 26: 175-82.

50. Singh A, Misra V, Thimmulappa RK, Lee H, Ames S, Hoque MO, et al. Dysfunctional KEAP1-NRF2 interaction in non-small- cell lung cancer. PLoS Med. 2006; 3: e420. doi: 10.1371/journal. pmed.0030420.
51. Shibata T, Kokubu A, Gotoh M, Ojima H, Ohta T, Yamamoto M, et al. Genetic alteration of Keap1 confers constitutive Nrf2 activation and resistance to chemotherapy in gallbladder cancer. Gastroenterology. 2008 135: 1358-68.e4.

52. Shibata T, Ohta T, Tong KI, Kokubu A, Odogawa R, Tsuta K, et al. Cancer related mutations in NRF2 impair its recognition by Keap1Cul3 E3 ligase and promote malignancy. Proc Natl Acad Sci. 2008. 105: 13568-73.

53. Abid Z, Cross AJ, Sinha R. Meat, dairy, and cancer. Am J Clin Nutr. 2014; 100: 386S-93S

54. Bernstein AM, Song M, Zhang X, Pan A, Wang M, Fuchs CS, et al. Processed and unprocessed red meat and risk of colorectal cancer: analysis by tumor location and modification by time. PLoS One. 2015; 10: e0135959. doi: 10.1371/journal.pone.0135959.

55. English DR, MacInnis RJ, Hodge AM, Hopper JL, Haydon AM, Giles GG. Red meat, chicken, and fish consumption and risk of colorectal cancer. Cancer Epidemiol Biomarkers Prev. 2004; 13: 1509-14.

56. Sandhu MS, White IR, McPherson K. Systematic review of the prospective cohort studies on meat consumption and colorectal cancer risk: a meta-analytical approach. Cancer Epidemiol Biomarkers Prev. 2001; 10: 439-46.

57. Watson AJM, Collins PD. Colon cancer: a civilization disorder. Dig Dis. 2011; 29: 222-8.

58. Bernstein C, Holubec H, Bhattacharyya AK, Nguyen H, Payne CM, Zaitlin B, et al. Carcinogenecity of deoxycholate, a secondary bile acid. Arch Toxicol. 2011; 85: 863-71.

59. Vipperla K, O'Keefe SJ. Intestinal microbes, diet, and colorectal cancer. Curr Colorectal Cancer Rep. 2013; 9: 95-105.

60. Hughes R, Magee EA, Bingham S. Protein degradation in the large intestine: relevance to colorectal cancer. Curr Issues Intest Microbiol. 2000; 1: 51-8.

61. Bos JL. Ras oncogenes in human cancer: a review. Cancer Res. 1989; 49: 4682-9.

61. Kobayashi J. Effect of diet and gut environment on the gastrointestinal formation of N-nitroso compounds: a review. Nitric Oxide. 2018; 73: 66-73.

63. Jeyakumar A, Dissabandara L, Gopalan V. A critical overview on the biological and molecular features of red and processed meat in colorectal carcinogenesis. J Gastroenterol. 2017; 52: 407-18.

64. Fearon ER. Molecular genetics of colorectal cancer. Annu Rev Pathol. 2011; 6: 479-507.

65. Lamprecht SA. Lipkin M. Migrating colonic crypt epithelial cells: primary targets for transformation. Carcinogenesis. 2002; 23: 1777 80.

66. Pierre F, Freeman A, Taché S, Van der Meer R, Corpet DE. Beef meat and blood sausage promote the formation of azoxymethane-induced mucin-depleted foci and aberrant crypt foci in rat colons. J Nutr. 2004; 134: 2711-6.

67. Gilsing AMJ, Fransen F, de Kok TM, Goldbohm AR, Schouten LJ, de Bruine AP, et al. Dietary heme iron and the risk of colorectal cancer with specific mutations in KRAS and APC. Carcinogenesis. 2013; 34: 2757-66.

68. Schneikert J, Behrens J. The canonical Wnt signalling pathway and its APC partner in colon cancer development. Gut. 2007; 56: 417-25.

69. Gamage SMK, Dissabandara L, Lam AKY, Gopalan V. The role of heme iron molecules derived from red and processed meat in the pathogenesis of colorectal carcinoma. Crit Rev Oncol Hematol. 2018; 126: 121-8.

70. Sporn MB, Dunlop NM, Newton DL, Smith JM. Prevention of chemical carcinogenesis by vitamin A and its synthetic analogs (retinoids). Fed Proc. 1976; 35: 1332-8. 
71. Landis-Piwowar KR, Iyer N. Cancer chemoprevention: current state of the art. Cancer Growth Metastasis. 2014; 7: 19-25.

72. De Flora S, Ferguson LR. Overview of mechanisms of cancer chemopreventive agents. Mutat Res. 2005; 591: 8-15.

73. Steward WP, Brown K. Cancer chemoprevention: a rapidly evolving field. Br J Cancer. 2013; 109: 1-7.

74. Shu L, Cheung KL, Khor TO, Chen C, Kong AN. Phytochemicals: cancer chemoprevention and suppression of tumor onset and metastasis. Cancer Metastasis Rev. 2010; 29: 483-502.

75. Vanden Berghe W. Epigenetic impact of dietary polyphenols in cancer chemoprevention: lifelong remodeling of our epigenomes. Pharmacol Res. 2012; 65: 565-76.

76. Gan FF, Ling H, Ang X, Reddy SA, Lee SSH, Yang H, et al. A novel shogaol analog suppresses cancer cell invasion and inflammation, and displays cytoprotective effects through modulation of NF-kB and Nrf2-Keap1 signaling pathways. Toxicol Appl Pharmacol. 2013; 272: 852-62.

77. Yager JD, Davidson NE. Estrogen carcinogenesis in breast cancer. N Eng1 J Med. 2006; 354: 270-82.

78. Din FVN, Valanciute A, Houde VP, Zibrova D, Green KA, Sakamoto $\mathrm{K}$, et al. Aspirin inhibits mTOR signaling, activates AMP-activated protein kinase, and induces autophagy in colorectal cancer cells. Gastroenterology. 2012; 142: 1504-15.e3.

79. Yang H, Landis-Piwowar K, Chan TH, Dou QP. Green tea polyphenols as proteasome inhibitors: implication in chemoprevention. Curr Cancer Drug Targets. 2011; 11: 296-306.

80. Bruno RD, Njar VC. Targeting cytochrome P450 enzymes: a new approach in anti-cancer drug development. Bioorg Med Chem. 2007; 15: 5047-60.

81. Landis-Piwowar K, Chen D, Chan TH, Dou QP. Inhibition of catechol-omicron-methyltransferase activity in human breast cancer cells enhances the biological effect of the green tea polyphenol (-)EGCG. Oncol Rep. 2010; 24: 563-69.

82. Kuang S, Qi C, Liu J, Sun X, Zhang Q, Sima Z, et al. 2-Methoxystypandrone inhibits signal transducer and activator of transcription 3 and nuclear factor- $\mathrm{kB}$ signaling by inhibiting Janus kinase 2 and IкB kinase. Cancer Sci. 2014; 105: 473-80.

83. Wu DG, Yu P, Li JW, Jiang P, Sun J, Wang HZ, et al. Apigenin potentiates the growth inhibitory effects by IKK- $\beta$-mediated NF- $\mathrm{KB}$ activation in pancreatic cancer cells. Toxicol Lett. 2014; 224: 15764.

84. Jaramillo MC, Zhang DD. The emerging role of the Nrf2-Keap1 signaling pathway in cancer. Genes Dev. 2013; 27: 2179-91.

85. Dinkova-Kostova AT, Fahey JW, Kostov RV, Kensler TW. KEAP1 and done? targeting the NRF2 pathway with sulforaphane. Trends Food Sci Technol. 2017; 69: 257-69.

86. Sohn EJ, Park HT. Natural agents mediated autophagic signal networks in cancer. Cancer Cell Int. 2017; 17: 110. doi: 10.1186/ s12935-017-0486-7.

87. Deep G, Gangar SC, Agarwal C, Agarwal R. Role of E-cadherin in antimigratory and antiinvasive efficacy of silibinin in prostate cancer cells. Cancer Prev Res. 2011; 4: 1222-32.

88. Zhu FQ, Chen MJ, Zhu M, Zhao RS, Qiu W, Xu X, et al. Curcumin suppresses epithelial-mesenchymal transition of renal tubular epithelial cells through the inhibition of Akt/mTOR pathway. Biol Pharm Bull. 2017; 40: 17-24.

89. Ji Q, Liu X, Han Z, Zhou L, Sui H, Yan L, et al. Resveratrol suppresses epithelial-to-mesenchymal transition in colorectal cancer through TGF- $\beta 1 /$ Smads signaling pathway mediated Snail/E-cadherin expression. BMC Cancer. 2015; 15: 97. doi: 10.1186/s12885-0151119-y.

90. Jaramillo MC, Zhang DD. The emerging role of the Nrf2-Keap1 signaling pathway in cancer. Genes Dev. 2013; 27: 2179-91.
91. Nguyen T, Nioi P, Pickett CB. The Nrf2-antioxidant response element signaling pathway and its activation by oxidative stress. J Biol Chem. 2009; 284: 13291-5.

92. Baylin SB, Jones PA. A decade of exploring the cancer epigenomebiological and translational implications. Nat Rev Cancer. 2011; 11: 726-34.

93. Jones PA, Baylin SB. The fundamental role of epigenetic events in cancer. Nat Rev Genet. 2002; 3: 415-28

94. Jones PA, Baylin SB. The epigenomics of cancer. Cell. 2007; 128: 683-92.

95. Wellen KE, Thompson CB. Cellular metabolic stress: considering how cells respond to nutrient excess. Mol Cell. 2010; 40: 323-32.

96. Azad N, Zahnow CA, Rudin CM, Baylin SB. The future of epigenetic therapy in solid tumours-lessons from the past. Nat Rev Clin Oncol. 2013; 10: 256-66.

97. Ahuja N, Easwaran H, Baylin SB. Harnessing the potential of epigenetic therapy to target solid tumors. J Clin Invest. 2014; 124 56-63.

98. Michels KB, Mohllajee AP, Roset-Bahmanyar E, Beehler GP, Moysich KB. Diet and breast cancer: a review of the prospective observational studies. Cancer. 2007; 109: 2712-49.

99. Vainio $\mathrm{H}$, Weiderpass E. Fruit and vegetables in cancer prevention Nutr Cancer. 2006; 54: 111-42

100. Liu RH. Potential synergy of phytochemicals in cancer prevention: mechanism of action. J Nutr. 2004; 134: 3479S-85S.

101. Kim MK, Park JH. Cruciferous vegetable intake and the risk of human cancer: epidemiological evidence. Proc Nutr Soc. 2009; 68 : 103-10. h

102. Liu X, Ly K. Cruciferous vegetables intake is inversely associated with risk of breast cancer: a meta-analysis. The Breast. 2013; 22 309-13.

103. Kirsh VA, Peters U, Mayne ST, Subar AF, Chatterjee N, Johnson CC, et al. Prospective study of fruit and vegetable intake and risk of prostate cancer. J Natl Cancer Inst. 2007; 99: 1200-9.

104. Verhoeven DT, Verhagen H, Goldbohm RA, van den Brandt PA, van Poppel G. A review of mechanisms underlying anticarcinogenicity by brassica vegetables. Chem Biol Interact. 1997; 103: 79-129.

105. Talalay P, Fahey JW, Holtzclaw WD, Prestera T, Zhang Y. Chemoprotection against cancer by phase 2 enzyme induction. Toxicol Lett. 1995; 82-83: 173-9.

106. Zhang Y, Talalay P. Anticarcinogenic activities of organic isothiocyanates: chemistry and mechanisms. Cancer Res. 1994; 54 1976s-81s.

107. Fowke JH, Longcope C, Hebert JR. Brassica vegetable consumption shifts estrogen metabolism in healthy postmenopausal women. Cancer Epidemiol Biomarkers Prev. 2000; 9: 773-9.

108. Meng Q, Yuan F, Goldberg ID, Rosen EM, Auborn K, Fan S. Indole-3carbinol is a negative regulator of estrogen receptor-alpha signaling in human tumor cells. J Nutr. 2000; 130: 2927-31.

109. Hsing AW, McLaughlin JK, Schuman LM, Bjelke E, Gridley G, Wacholder S, et al. Diet, tobacco use, and fatal prostate cancer: results from the Lutheran Brotherhood Cohort Study. Cancer Res. 1990; 50: 6836-40

110. Giovannucci E, Rimm EB, Liu Y, Stampfer MJ, Willett WC. A prospective study of cruciferous vegetables and prostate cancer. Cancer Epidemiol Biomarkers Prev. 2003; 12: 1403-9.

111. Stram DO, Hankin JH, Wilkens LR, Park S, Henderson BE, Nomura AMY, et al. Prostate cancer incidence and intake of fruits, vegetables and related micronutrients: the multiethnic cohort study* (United States). Cancer Causes Control. 2006; 17: 1193-207.

112. Riso P, Martini D, Moller P, Loft S, Bonacina G, Moro M, et al. DNA damage and repair activity after broccoli intake in young healthy smokers. Mutagenesis. 2010; 25: 595-602. 
113. Munday R, Mhawech-Fauceglia P, Munday CM, Paonessa JD, Tang L, Munday JS, et al. Inhibition of urinary bladder carcinogenesis by broccoli sprouts. Cancer Res. 2008; 68: 1593-600.

114. Wakabayashi N, Slocum SL, Skoko JJ, Shin S, Kensler TW.When NRF2 talks, who's listening? Antioxid Redox Signal. 2010; 13: 1649-63.

115. Licznerska B, Szaefer H, Matuszak I, Murias M, Baer-Dubowska W. Modulating potential of L-sulforaphane in the expression of cytochrome p450 to identify potential targets for breast cancer chemoprevention and therapy using breast cell lines. Phytother Res. 2015; 29: 93-9.

116. Seeram NP, Henning SM, Niu Y, Lee R, Scheuller HS, Heber D. Catechin and caffeine content of green tea dietary supplements and correlation with antioxidant capacity. J Agric Food Chem. 2006; 54: 1599-603.

117. Wang LG, Liu XM, Chiao JW. Repression of androgen receptor in prostate cancer cells by phenethyl isothiocyanate. Carcinogenesis. 2006; 27: 2124-32.

118. Hwang ES, Lee HJ. Effects of phenylethyl isothiocyanate and its metabolite on cell-cycle arrest and apoptosis in LNCaP human prostate cancer cells. Int J Food Sci Nutr. 2010; 61: 324-36.

119. Gibbs A, Schwartzman J, Deng V, Alumkal J. Sulforaphane destabilizes the androgen receptor in prostate cancer cells by inactivating histone deacetylase 6. Proc Natl Acad Sci USA. 2009; 106: $16663-8$.

120. Torre LA, Bray F, Siegel RL, Ferlay J, Lortet-Tieulent J, Jemal A. Global cancer statistics, 2012. CA Cancer J Clin. 2015; 65: 87-108.

121. Aleksandrova K, Pischon T, Jenab M, Bueno-de-Mesquita HB, Fedirko V, Norat T, et al. Combined impact of healthy lifestyle factors on colorectal cancer: a large European cohort study. BMC Med. 2014; 12: 168. doi: 10.1186/s12916-014-0168-4.

122. Garcia DO, Thomson CA. Physical activity and cancer survivorship. Nutr Clin Pract. 2014; 29: 768-79.

123. Mehta M, Shike M. Diet and physical activity in the prevention of colorectal cancer. J Natl Compr Canc Netw. 2014; 12: 1721-6.

124. Howes MJ, Simmonds MS. The role of phytochemicals as micronutrients in health and disease. Curr Opin Clin Nutr Metab Care. 2014; 17: 558-66.

125. Murakami A. Chemoprevention with phytochemicals targeting inducible nitric oxide synthase. Forum Nutr. 2009; 61: 193-203.

126. Priyadarsini RV, Nagini S. Cancer chemoprevention by dietary phytochemicals: promises and pitfalls. Curr Pharm Biotechnol. 2012; 13: 125-36.

127. Lee KW, Bode AM, Dong Z. Molecular targets of phytochemicals for cancer prevention. Nat Rev Cancer. 2011; 11: 211-8.

128. Loeb LA, Harris CC. Advances in chemical carcinogenesis: a historical review and prospective. Cancer Res. 2008; 68: 6863-72.

129. Tokarz P, Blasiak J. Role of mitochondria in carcinogenesis. Acta Biochim Pol. 2014; 61: 671-8.

130. Barcellos-Hoff MH, Lyden D, Wang TC. The evolution of the cancer niche during multistage carcinogenesis. Nat Rev Cancer. 2013; 13 511-8.

131. Kotecha R, Takami A, Espinoza JL. Dietary phytochemicals and cancer chemoprevention: a review of the clinical evidence. Oncotarget. 2016; 7: 52517-29.

132. Kim R, Emi M, Tanabe K. Cancer immunoediting from immune surveillance to immune escape. Immunology. 2007; 121: 1-14.

133. Collins AR, Azqueta A, Langie SA. Effects of micronutrients on DNA repair. Eur J Nutr. 2012; 51: 261-79.

134. Royston KJ, Tollefsbol TO. The epigenetic impact of cruciferous vegetables on cancer prevention. Curr Pharmacol Rep. 2015; 1: 4651.
135. Luis Espinoza J, Takami A, Trung LQ, Nakao S. Ataxia-telangiectasia mutated kinase-mediated upregulation of NKG2D ligands on leukemia cells by resveratrol results in enhanced natural killer cell susceptibility. Cancer Sci. 2013; 104: 657-62.

136. Slamenova D, Horvathova E. Cytotoxic, anti-carcinogenic and antioxidant properties of the most frequent plant volatiles. Neoplasma. 2013; 60: 343-354

137. Chen D, Daniel KG, Chen MS, Kuhn DJ, Landis-Piwowar KR, Dou QP. Dietary flavonoids as proteasome inhibitors and apoptosis inducers in human leukemia cells. Biochem Pharmacol. 2005; 69: 1421-32.

138. Chan SN, Tang BL. Location and membrane sources for autophagosome formation - from ER-mitochondria contact sites to Golgi-endosome-derived carriers. Mol Membr Biol. 2013; 30: 394 402.

139. Gao H, Sun W, Zhao W, Hao W, Leung CH, Lu J, et al. Total tanshinones-induced apoptosis and autophagy via reactive oxygen species in lung cancer 95D cells. Am J Chin Med. 2015; 43: 126579.

140. Meng Y, Lin ZM, Ge N, Zhang DL, Huang J, Kong F. Ursolic acid induces apoptosis of prostate cancer cells via the PI3K/Akt/mTOR pathway. Am J Chin Med. 2015; 43: 1471-86.

141. Wang K, Liu R, Li J, Mao J, Lei Y, Wu J, et al. Quercetin induces protective autophagy in gastric cancer cells: involvement of AktmTOR-and hypoxia-induced factor 1alpha-mediated signaling. Autophagy. 2011; 7: 966-78.

142. Suh Y, Afaq F, Khan N, Johnson JJ, Khusro FH, Mukhtar H. Fisetin induces autophagic cell death through suppression of mTOR signaling pathway in prostate cancer cells. Carcinogenesis. 2010; 31: 1424-33.

143. Ge J, Liu Y, Li Q, Guo X, Gu L, Ma ZG, et al. Resveratrol induces apoptosis and autophagy in T-cell acute lymphoblastic leukemia cells by inhibiting Akt/mTOR and activating p38-MAPK. Biomed Environ Sci BES. 2013; 26: 902-11.

144. Yeh PS, Wang W, Chang YA, Lin CJ, Wang JJ, Chen RM. Honokiol induces autophagy of neuroblastoma cells through activating the PI3K/Akt/mTOR and endoplasmic reticular stress/ERK1/2 signaling pathways and suppressing cell migration. Cancer Lett. 2016; 370: 66-77.

145. Zheng X, Chen W, Hou H, Li J, Li H, Sun X, et al. Ginsenoside 20(S)$\mathrm{Rg} 3$ induced autophagy to inhibit migration and invasion of ovarian cancer. Biomed Pharmacother Biomed Pharmacother. 2017; 85: 620-6.

146. Xavier CP, Lima CF, Pedro DF, Wilson JM, Kristiansen K, PereiraWilson C. Ursolic acid induces cell death and modulates autophagy through JNK pathway in apoptosis-resistant colorectal cancer cells. J Nutr Biochem. 2013; 24: 706-12.

147. Zheng K, Li Y, Wang S, Wang X, Liao C, Hu X, et al. Inhibition of autophagosome-lysosome fusion by ginsenoside Ro via the ESR2-NCF1-ROS pathway sensitizes esophageal cancer cells to 5-fluorouracil-induced cell death via the CHEK1-mediated DNA damage checkpoint. Autophagy. 2016; 12: 1593-613.

148. Shehzad A, Wahid F, Lee YS. Curcumin in cancer chemoprevention: molecular targets, pharmacokinetics, bioavailability, and clinical trials. Arch Pharm (Weinheim). 2010; 343: 489-99.

149. Bar-Sela G, Epelbaum R, Schaffer M. Curcumin as an anti-cancer agent: review of the gap between basic and clinical applications. Curr Med Chem. 2010; 17: 190-7.

150. Hasima N, Aggarwal BB. Targeting proteasomal pathways by dietary curcumin for cancer prevention and treatment. Curr Med Chem. 2014; 21: 1583-94.

151. Bortel N, Armeanu-Ebinger S, Schmid E, Kirchner B, Frank J, Kocher 
A, et al. Effects of curcumin in pediatric epithelial liver tumors: inhibition of tumor growth and alpha-fetoprotein in vitro and in vivo involving the NFkappaB- and the beta-catenin pathways. Oncotarget. 2015; 6: 40680-91.

152. Keylor MH, Matsuura BS, Stephenson CR. Chemistry and biology of resveratrol-derived natural products. Chem Rev. 2015; 115: 89769027.

153. Espinoza JL, Takami A, Trung LQ, Kato S, Nakao S. Resveratrol prevents EBV transformation and inhibits the outgrowth of EBVimmortalized human B cells. PLoS One. 2012; 7: e51306. doi: 10.1371/journal.pone.0051306.

154. Scott E, Steward WP, Gescher AJ, Brown K. Resveratrol in human cancer chemoprevention--choosing the 'right' dose. Mol Nutr Food Res. 2012; 56: 7-13.

155. Shukla Y, Singh R. Resveratrol and cellular mechanisms of cancer prevention. Ann NY Acad Sci. 2011; 1215: 1-8.

156. Kato A, Naiki-Ito A, Nakazawa T, Hayashi K, Naitoh I, Miyabe $\mathrm{K}$, et al. Chemopreventive effect of resveratrol and apocynin on pancreatic carcinogenesis via modulation of nuclear phosphorylated GSK3 $\beta$ and ERK1/2. Oncotarget. 2015; 6: 42963-75.

157. Patel KR, Scott E, Brown VA, Gescher AJ, Steward WP, Brown K. Clinical trials of resveratrol. Ann NY Acad Sci. 2011; 1215: 161-9.

158. Seeni A, Takahashi S, Takeshita K, Tang M, Sugiura S, Sato SY, et al. Suppression of prostate cancer growth by resveratrol in the transgenic rat for adenocarcinoma of prostate (TRAP) model. Asian Pac J Cancer Prev. 2008; 9: 7-14.

159. Seeram NP, Henning SM, Niu Y, Lee R, Scheuller HS, Heber D. Catechin and caffeine content of green tea dietary supplements and correlation with antioxidant capacity. J Agric Food Chem. 2006; 54: 1599-603.

160. Wu AH, Yu MC. Tea, hormone-related cancers and endogenous hormone levels. Mol Nutr Food Res. 2006; 50: 160-9.

161. Yiannakopoulou EC. Effect of green tea catechins on breast carcinogenesis: a systematic review of in-vitro and in-vivo experimental studies. Eur J Cancer Prev. 2014; 23: 84-9.

162. Steele VE, Kelloff GJ, Balentine D, Boone CW, Mehta R, Bagheri $\mathrm{D}$, et al. Comparative chemopreventive mechanisms of green tea, black tea and selected polyphenol extracts measured by in vitro bioassays. Carcinogenesis. 2000; 21: 63-7.

163. Glasauer A, Chandel NS. Targeting antioxidants for cancer therapy. Biochem Pharmacol. 2014; 92: 90-101.

164. Bailey LB, Gregory JF. Folate metabolism and requirements. J Nutr. 1999; 129: 779-82.

165. Dary O. Nutritional interpretation of folic acid interventions. Nutr Rev. 2009; 67: 235-44.

166. Chen P, Li C, Li X, Li J, Chu R, Wang H. Higher dietary folate intake reduces the breast cancer risk: a systematic review and metaanalysis. Br J Cancer. 2014; 110: 2327-38.

167. Shi J, Le Maguer M. Lycopene in tomatoes: chemical and physical properties affected by food processing. Crit Rev Biotechnol. 2000; 20: 293-334

168. Palozza P, Parrone N, Catalano A, Simone R. Tomato lycopene and inflammatory cascade: basic interactions and clinical implications. Curr Med Chem. 2010; 17: 2547-63.

169. Ono M, Takeshima M, Nakano S. Mechanism of the anticancer effect of lycopene (tetraterpenoids). Enzymes. 2015; 37: 139-66.

170. Key TJ, Appleby PN, Travis RC, Albanes D, Alberg AJ, Barricarte A, et al. Carotenoids, retinol, tocopherols, and prostate cancer risk: pooled analysis of 15 studies. Am J Clin Nutr. 2015; 102: 1142-57.

171. Chen J, Song Y, Zhang L. Lycopene/tomato consumption and the risk of prostate cancer: a systematic review and meta-analysis of prospective studies. J Nutr Sci Vitaminol. 2013; 59: 213-23.

172. Ilic D, Forbes KM, Hassed C. Lycopene for the prevention of prostate cancer. Cochrane Database Syst Rev. 2011: 2011; CD008007.

173. Budhraja A, Gao N, Zhang Z, Son Y-O, Cheng S, Wang X, et al. Apigenin induces apoptosis in human leukemia cells and exhibits anti-leukemic activity in vivo. Mol Cancer Ther. 2012; 11: 132-42.

174. Byun S, Park J, Lee E, Lim S, Yu JG, Lee SJ, et al. Src kinase is a direct target of apigenin against UVB-induced skin inflammation. Carcinogenesis. 2013; 34: 397-405.

175. Shukla S, Gupta S. Molecular targets for apigenin-induced cell cycle arrest and apoptosis in prostate cancer cell xenograft. Mol Cancer Ther. 2006; 5: 843-52.

176. Shukla S, MacLennan GT, Flask CA, Fu P, Mishra A, Resnick MI, et al. Blockade of beta-catenin signaling by plant flavonoid apigenin suppresses prostate carcinogenesis in TRAMP mice. Cancer Res. 2007; 67: 6925-35.

177. Nicholas C, Batra S, Vargo MA, Voss OH, Gavrilin MA, Wewers $\mathrm{MD}$, et al. Apigenin blocks lipopolysaccharide-induced lethality in vivo and proinflammatory cytokines expression by inactivating NF-kB through the suppression of p65 phosphorylation. J Immunol. 2007; 179: 7121-7.

178. Lee SH, Ryu JK, Lee K-Y, Woo SM, Park JK, Yoo JW, et al. Enhanced anti-tumor effect of combination therapy with gemcitabine and apigenin in pancreatic cancer. Cancer Lett. 2008; 259: 39-49.

179. Ruiz PA, Haller D. Functional diversity of flavonoids in the inhibition of the proinflammatory NF-kB, IRF, and Akt signaling pathways in murine intestinal epithelial cells. J Nutr. 2006; 136: 664-71.

180. Shukla S, Gupta S. Suppression of constitutive and tumor necrosis factor alpha-induced nuclear factor NF-kB activation and induction of apoptosis by apigenin in human prostate carcinoma PC-3 cells: correlation with down-regulation of NF-kB-responsive genes. Clin Cancer Res. 2004; 10: 3169-78. 